\title{
Synthesis, Spectroscopic and Preliminary Antimicrobial Studies of Some Schiff Base Ligands; N'N'-Ethylene Bis(salicylidenimine) and N,N'-Bis (salicylidene)-3,5-Diaminobenzoic Acid and their Metal Complexes
}

\author{
Ugwu Mariagoretti $\mathbf{O}^{\mathbf{1}}$, Ayuk Eugene $\mathrm{L}^{\mathbf{1}^{*}}$, Okeke Chinelo $\mathbf{C}^{\mathbf{1}}$, Aronimo Samuel $\mathrm{B}^{\mathbf{2}}$ \\ ${ }^{1}$ Chemical Sciences Department, Faculty of Natural and Applied Sciences, Godfrey Okoye University, \\ Ugwиоти-Nike, Enugu, Nigeria \\ ${ }^{2}$ Department of Chemistry Kogi State College of Education (Technical) Kabba, Kogi State, Nigeria \\ *Corresponding Author: Ayuk Eugene L, Chemical Sciences Department, Faculty of Natural and \\ Applied Sciences, Godfrey Okoye University, Ugwuomu-Nike, Enugu, Nigeria
}

\begin{abstract}
The $\mathrm{Mg}(\mathrm{II}), \mathrm{Fe}(\mathrm{II}), \mathrm{Pb}(\mathrm{II}), \mathrm{Cd}(\mathrm{II})$ and $\mathrm{Co}(\mathrm{II})$ metal complexes, were synthesized by coupling the above metals with two Schiff bases, $N, N^{\prime}$-ethylene bis-(salicylidenimine) and $N, N^{\prime}$ bis (salicylidene)-3,5diaminobenzoic acid respectively. The first ligand, $N, N^{\prime}$-ethylene bis (salicylidenimine) was obtained by the condensation reaction of salicyaldehyde and ethylenediamine while the second, $N, N^{\prime}$ bis (salicylidene)-3,5diamino benzoic was formed by the reaction of salicyaldehyde and 3,5-diaminobenzoic acid. The characterization of these ligands and their complexes was on the basis of their melting points, electronic spectra, and IR. These ligands as well as their complexes were screened for anti-microbial activity against some gram negative and gram positive organisms and they showed some measure of inhibition against the organisms.
\end{abstract}

Keywords: $\quad N, N^{\prime}$-Ethylene bis-(salicylidenimine), $\quad$,N'bis-(salicylidene)-3,5-diaminobenzoic acid, Salicyaldehyde, Ethylenediamine, Gram positive, Gram negative.

\section{INTRODUCTION}

Schiff bases are organic ligands which contain azomethine group $\mathrm{R}-\mathrm{C}=\mathrm{N}$. They are generally prepared by condensation of primary amines $\left(-\mathrm{NH}_{2}\right)$ with active carbonyl compounds like aldehyde or ketones $(\mathrm{C}=\mathrm{O})$. [1] [2]. Schiff base derived from aromatic amines and aromatic aldehydes have a wide variety of application in many fields such as biological, inorganic and analytical chemistry [3]. Transition metals are known to form complexes with Schiff bases and theses bases are used as chelating ligands in the field of coordination chemistry [4] .They are also useful in transamination processes [5]. Schiff bases have many important biological activities which include antimicrobial, antitumor and anti. HIV activities etc. [6][7] [8][9]. The aim of this study is to synthesize some new Schiff base ligands by capping the amine groups in diaminobenzoic acid and ethylenediamine with the carbonyl group from salicyaldehyde, couple the following transition metals, $\mathrm{Cd}$ (II), $\mathrm{Co}$ (II), $\mathrm{Fe}(\mathrm{II})$, $\mathrm{Mg}(\mathrm{II})$ and $\mathrm{Pb}(\mathrm{II})$ with the above ligands to form complexes as well as characterize these ligands and their metal complexes on the basis of their melting points, electronic spectra, infrared spectroscopy and finally, determine their biological activities.

\section{EXPERIMENTAL}

\subsection{Material and Instrumentation}

All the chemicals used for the synthesis of the ligands and their metal complexes were of analytical grade. IR spectra used in the characterization of the ligands and their metal complexes where recorded using Shimadu, FTIR_8400S, and UV model: V2.30

\subsection{Preparation of N, N'-ethylene Bis (Salicylidenimine), $\mathbf{E L}_{1}$}

The ligand, $\mathrm{EL}_{1}$ was synthesized by mixing a solution of salicyaldehyde $(11.630 \mathrm{~g}, 0.095 \mathrm{~mol})$ in $250 \mathrm{ml}$ hot ethanol $(99 \%)$ and of ethylenediamine $(2.861 \mathrm{~g}, 0.048 \mathrm{~mol})$. The mixture was refluxed for 
Synthesis, Spectroscopic and Preliminary Antimicrobial Studies of Some Schiff Base Ligands; N'N'Ethylene Bis(salicylidenimine) and N,N'-Bis (salicylidene)-3,5-Diaminobenzoic Acid and their Metal Complexes

2hours and the yellow precipitate formed was filtered off, re-crystallized with ethanol and dried. This was kept in desiccators for farther use. [10]

\subsection{Preparation of $\mathbf{N}, \mathrm{N}^{\prime}$-Bis (salicylidene)-3,5-Diaminobenzoic Acid, $\mathrm{BL}_{2}$}

A solution of 3,5-diaminobenzoic acid $(0.33 \mathrm{~g}, 0.0021 \mathrm{~mol})$ in $99 \%$ absolute ethanol $(15 \mathrm{ml})$ and $0.01 \mathrm{M} \mathrm{NaOH}(12 \mathrm{ml})$ was slowly added to a solution of salicyaldehyde $(0.48 \mathrm{~g}, 0.004 \mathrm{~mol})$ in absolute ethanol $(20 \mathrm{ml})$. The reaction mixture was refluxed for 4 hours at $60^{\circ} \mathrm{C}$. The mixture was cooled and the colored precipitate formed was filtered and dried in a desiccator. [11] [12]

\subsection{Synthesis of $\mathrm{EL}_{1}$ Complexes}

Generally, the metal compounds and the various Schiff base ligands were reacted together in a stochiometric mole ratio of 1.1. The $\mathrm{Fe}$ (II), $\mathrm{Pb}$ (II) and $\mathrm{Mg}$ (II) $\mathrm{EL}_{1}$ complexes were prepared as fellows: The metal chlorides and nitrates $(0.01$ mole $, 1.26 \mathrm{~g}, 3.312 \mathrm{~g}$, and $1.48 \mathrm{~g})$ respectively in warmed ethanol $(25 \mathrm{ml})$ were added to a solution of $\mathrm{EL}_{1}(0.01 \mathrm{~mole})$ in $85 \%$ of warmed ethanol respectively. The mixtures were refluxed for one hour and after the reactions, the resulting solutions were filtered and re-crystallized with ethanol and allowed in desiccators.

\subsection{Synthesis of $\mathrm{BL}_{2}$ Complexes}

The synthesis of Co \& Cd complexes of $N, N^{\prime}$-bi s(salicylidene)-3,5-diaminobenzioc acid was carried out thus; A solution of a $\mathrm{BL}_{2}(0.33 \mathrm{~g}, 0.01 \mathrm{~mole})$ in absolute ethanol $(20 \mathrm{ml})$ and those of the Co and $\mathrm{Cd}$ (II) chlorides respectively in (99\%) ethanol $(25 \mathrm{ml})$ were mixed and refluxed for 4 hours. Black colored precipitates of $\mathrm{Cd}(\mathrm{II})$ and $\mathrm{Co}$ (II) were obtained and then filtered, followed by repeated washing with cold ethanol. They were later dried in desiccators.

\section{RESULT AND DISCUSSION}

\subsection{Physical Properties of the Synthesized Compounds}

$N, N$ '-Ethylene bis (salicylidenimine), $\mathrm{EL}_{1}$ and its $\mathrm{Mg}$ (II) complex, $\left[\mathrm{MgEL}_{1}\right]$ were observed to be crystalline yellowish compound melting at $90^{\circ} \mathrm{C}$ and $104^{\circ} \mathrm{C}$, respectively. The $\mathrm{PbEL}_{1}$, was a whitish crystalline complex with melting at over $369^{\circ} \mathrm{C}$, while $\mathrm{FeEL}_{1}$ was a brownish powdery compound with a melting point of $70^{\circ} \mathrm{C}$.

$N, N^{\prime}$-Bis (salicylidene)-3, 5-diaminobenzoic acid, $\mathrm{BL}_{2}$ was observed to be a black in powdery substance at $200^{\circ} \mathrm{C}$. Both cadmium complex $\left(\mathrm{CdBL}_{2}\right)$ and cobalt complex $\left(\mathrm{CoBL}_{2}\right)$ were observed blackish powdery compounds; however their melting points were not determined. Generally, the all the synthesized compounds gave good percentage yields; the only exceptions are lead (IV) complex $\left(\mathrm{PbEL}_{1}\right)$ and iron (II) complex $\left(\mathrm{FeEL}_{1}\right)$ respectively.

The physical properties and the percentage yields of the ligand and the metal complexes are presented in Table 3.1 below;

Table1. Physical properties of the ligands and the metal complexes

\begin{tabular}{|c|c|c|c|c|}
\hline Compound & Colour & Texture & Melting point $\left({ }^{\circ} \mathrm{C}\right)$ & \% Yield \\
\hline $\mathrm{EL}_{1}$ & Yellow & Crystalline & 90 & 76.27 \\
\hline $\mathrm{MgEL}_{1}$ & Yellow & Crystalline & 104 & 65.06 \\
\hline $\mathrm{PbEL}_{1}$ & Milky & Crystalline & $>369$ & 31.78 \\
\hline $\mathrm{FeEL}_{1}$ & Brownish & Powdery & 70 & 20.43 \\
\hline $\mathrm{BL}_{2}$ & Black & Powdery & 200 & 65.71 \\
\hline $\mathrm{CdBL}_{2}$ & Black & Powdery & ND & 63.82 \\
\hline $\mathrm{CoBL}_{2}$ & Grey & Powdery & ND & 63.82 \\
\hline
\end{tabular}

ND= Not determined

\subsection{UV-Visible Spectra of Ligand and their Metal Complexes}

The electronic spectra of $\mathrm{EL}_{1}$, and its $\mathrm{MgEL}_{1}, \mathrm{PbEL}_{1}$, and $\mathrm{FeEL}_{1}$ complexes as shown in Table 3.2 below are similar to each other with regards to the positions of the absorption bands and their intensities. The spectra of $\mathrm{EL}_{1}$ shows broad band at $408.5 \mathrm{~nm}$ with an absorbance of 0.757 and a 
Synthesis, Spectroscopic and Preliminary Antimicrobial Studies of Some Schiff Base Ligands; N'N'Ethylene Bis(salicylidenimine) and N,N'-Bis (salicylidene)-3,5-Diaminobenzoic Acid and their Metal Complexes

molar absorptivity of 3160.79 . These absorption bands observed are due to $\pi \rightarrow \pi^{*}$ transitions and $n \rightarrow$ $\pi^{*}$ transitions of the non-bonding in the ligand.

In the spectrum of $\mathrm{MgEL}_{1}$, a broad band at $408 \mathrm{~nm}$ with an absorbance of 0.405 and a molar absorptivity of 3156.92 was observed. These values when compared to the ligand showed no difference. This is mainly because complexation did not take place owing to the fact that $\mathrm{Mg}$ (II) ion used is not a transition metal.

In the spectrum of $\mathrm{PbEL}_{1}$, three weak absorption bands at $756.00 \mathrm{~nm}, 713.00 \mathrm{~nm}$ and $494.50 \mathrm{~nm}$ were observed. Their absorbances were obtained at $0.090,0.091$ and 0.125 respectively while their molar absorptivities were calculated as 5849.59, 5516.87, and 3826.22 respectively. These weak bands displays bathochromic shifts when compared to their ligand and also their absorption is attributed to $\pi \rightarrow \pi^{*}$ transitions.

In the spectrum of $\mathrm{FeEL}_{1}$, two absorption bands ranging from strong to weak intensities were observed at $457.5 \mathrm{~nm}$, and $291 \mathrm{~nm}$ were observed. Their absorbances were obtained at 0.744 and 2.783 respectively while their molar absorptivities were calculated as 3539.93 and 2251.62 respectively. The strong bands displays a hypsochromic shifts when compared to their ligand and also this is an evidence that complexation has occurred.

The electronic absorption spectral data of the Schiff bases and their metal complexes are presented in Table 3.2 below;

Table2. Electronic spectral data of the Schiff bases and their metal complexes

\begin{tabular}{|l|l|l|l|}
\hline Compound & Wavelength(nm) & Absorbance & Molar Absorptivity \\
\hline $\mathrm{EL}_{1}$ & $408.50 \mathrm{br}$ & 0.757 & 3160.79 \\
\hline $\mathrm{MgEL}_{1}$ & $408.00 \mathrm{br}$ & 0.405 & 3156.92 \\
\hline $\mathrm{PbEL}_{1}$ & $756.00 \mathrm{w}$ & 0.090 & 5849.59 \\
\hline & $713.00 \mathrm{w}$ & 0.091 & 5516.87 \\
\hline & $494.50 \mathrm{w}$ & 0.125 & 3826.22 \\
\hline $\mathrm{FeEL}_{1}$ & $457.50 \mathrm{w}$ & 0.744 & 3539.93 \\
\hline & $291.00 \mathrm{~s}$ & 2.783 & 2251.62 \\
\hline $\mathrm{BL}_{2}$ & $366.50 \mathrm{~s}$ & 5,00 & 2835.81 \\
\hline $\mathrm{CdBL}_{2}$ & $427.00 \mathrm{~m}$ & 0.180 & 3303.93 \\
\hline & $362.50 \mathrm{w}$ & 0.100 & 2804.86 \\
\hline & $312.50 \mathrm{~s}$ & 0.270 & 2417.98 \\
\hline & $280.50 \mathrm{~s}$ & 0.572 & 2170.38 \\
\hline
\end{tabular}

* Intensities: s-strong, m-moderate, br-broad, w-weak, sh-shoulder

\subsection{IR Spectra of Ligands and their Metal Complexes}

The infrared spectra of $\mathrm{EL}_{1}$ and its complexes are presented in Table 3.3a. The spectrum of $\mathrm{EL}_{1}$ was much as expected. Bond formations were revealed by the presence of absorption bands in the 3500$3300 \mathrm{~cm}^{-1}$ region of the spectrum which is assigned to $\mathrm{O}-\mathrm{H}$ stretching. The presence of bands at $1750.46 \mathrm{~cm}^{-1}$ indicates the formation of an imine linkage $(\mathrm{C}=\mathrm{N})$. A broad absorption band at $1361.79 \mathrm{~cm}^{-1}$ indicates the presence of $\mathrm{C}=\mathrm{C}$ aromatic and $\mathrm{C}=\mathrm{O}$ stretching. At $1036.77 \mathrm{~cm}^{-1}$ a moderate band was observed indicating $\mathrm{CH}_{2}$ rocking and $\mathrm{C}-\mathrm{H}$ out of plane bend. Bands assignable to $(\mathrm{C}-\mathrm{C})$ ring stretching vibrations were obtained. Far-infrared analysis was not recorded for this ligand.

The spectra for $\mathrm{MgEL}_{1}, \mathrm{PbEL}_{1}$ and $\mathrm{FeEL}_{1}$ revealed no alteration in the stretching or bending frequencies of the $\mathrm{C}=\mathrm{C}$ aromatic, $\mathrm{C}=\mathrm{O}$ stretching, $\mathrm{CH}_{2}$ rocking and $\mathrm{C}-\mathrm{H}$ out of plane bend. Bands assignable to $(\mathrm{C}-\mathrm{C})$ ring stretching were still observed. A moderate shift of the absorption frequency of the ligand from $1750.46 \mathrm{~cm}^{-1}$ to lower frequencies of $1600.97 \mathrm{~cm}^{-1}, 1630.87 \mathrm{~cm}^{-1}$, and $1620.26 \mathrm{~cm}^{-1}$ as observed in the complexes $\mathrm{MgEL}_{1}, \mathrm{PbEL}_{1}$ and $\mathrm{FeEL}_{1}$ respectively suggests that complexation has occurred by involving the imine nitrogen as has been observed for some other schiff base complexes reported. Also the shift observed in the $\mathrm{O}-\mathrm{H}$ stretch of the ligand at $3371.64 \mathrm{~cm}^{-1}$ and those from the complexes i.e. $3007.12 \mathrm{~cm}^{-1}, 3349.50 \mathrm{~cm}^{-1}$, and $3343 \mathrm{~cm}^{-1}$ for $\mathrm{MgEL}_{1}, \mathrm{PbEL}_{1}$ and $\mathrm{FeEL}_{1}$ respectively suggests that complexation has occurred by involving the oxygen end as has been observed for some other reported cases. 
Synthesis, Spectroscopic and Preliminary Antimicrobial Studies of Some Schiff Base Ligands; N'N'Ethylene Bis(salicylidenimine) and N,N'-Bis (salicylidene)-3,5-Diaminobenzoic Acid and their Metal Complexes

Table3. Infrared Spectra of $E L_{1}$ and its Complexes $\left(\mathrm{cm}^{-1}\right)$

\begin{tabular}{|l|l|l|l|l|}
\hline EL $_{\mathbf{1}}$ & MgEL $_{\mathbf{1}}$ & PbEL $_{\mathbf{1}}$ & FeEL $_{\mathbf{1}}$ & Functional group \\
\hline $3371.64 \mathrm{br}$ & $3007.12 \mathrm{w}$ & $3349.50 \mathrm{w}$ & $3343 \mathrm{w}$ & O-H stretching \\
\hline $2737.08 \mathrm{~m}$ & $2907.72 \mathrm{~m}$ & $2738.05 \mathrm{w}$ & $2925.16 \mathrm{~m}$ & $\mathrm{C}-\mathrm{H}$ aromatic stretching \\
\hline $1750.46 \mathrm{~m}$ & $1600.97 \mathrm{~m}$ & $1630.87 \mathrm{~m}$ & $1620.26 \mathrm{~s}$ & $\mathrm{C}=\mathrm{O}$ stretching \\
\hline $1361.79 \mathrm{br}$ & $1406.15 \mathrm{~s}$ & $1367.58 \mathrm{br}$ & $1448.59 \mathrm{~s}$ & $\mathrm{C}=\mathrm{C}$ Aromatic, $\mathrm{C}=\mathrm{N}$ \\
\hline $1036.77 \mathrm{~m}$ & $1027.13 \mathrm{~s}$ & $1037.74 \mathrm{w}$ & $1042.56 \mathrm{~m}$ & $\mathrm{C}-\mathrm{C}, \mathrm{C}-\mathrm{O}$ \\
\hline $757.09 \mathrm{w}$ & $749.37 \mathrm{~s}$ & $753.23 \mathrm{w}$ & $759.98 \mathrm{~s}$ & $\mathrm{CH}_{2}$ rocking, $\mathrm{C}-\mathrm{H}$ out of plane bend \\
\hline $389.63 \mathrm{~s}$ & $467.75 \mathrm{~m}$ & $386.74 \mathrm{~s}$ & $430.14 \mathrm{~s}$ & $\mathrm{C}-\mathrm{C}$ ring \\
\hline
\end{tabular}

The infrared spectral data of $\mathrm{BL}_{2}$ and its complexes are presented in Table 3.4 below. The spectrum of $\mathrm{BL}_{2}$ was much as expected. Bond formations were revealed by the presence of absorption bands at $3760.35 \mathrm{~cm}^{-1}$ region of the spectrum which is assigned to $\mathrm{O}-\mathrm{H}$ stretching. The presence of bands at $1687.77 \mathrm{~cm}^{-1}$ indicates the presence of a carbonyl functionality $(\mathrm{C}=\mathrm{O})$. A strong absorption band at $1453.14 \mathrm{~cm}^{-1}$ indicates the formation of an imine linkage $(\mathrm{C}=\mathrm{N})$ as well as $\mathrm{C}=\mathrm{C}$ aromatic stretching. At $1137.07 \mathrm{~cm}^{-1}$ a strong band was observed indicating $\mathrm{C}-\mathrm{C}, \mathrm{C}-\mathrm{O}$ stretching. Bands assignable to $(\mathrm{C}-$ C) ring stretching vibrations were observed at $430.14 \mathrm{~cm}^{-1}$. Far-infrared analysis was not recorded for this ligand.

The spectra for $\mathrm{CdBL}_{2}$ and $\mathrm{CoBL}_{2}$ revealed no alteration in the stretching or bending frequencies of the $\mathrm{C}=\mathrm{C}$ aromatic, $\mathrm{C}=\mathrm{O}$ stretching, $\mathrm{CH}_{2}$ rocking and $\mathrm{C}-\mathrm{H}$ out of plane bend. Bands assignable to $(\mathrm{C}-$ C) ring stretching were still observed. A moderate shift of the absorption frequency of the ligand to lower frequencies as observed in the complexes suggests that complexation has occurred by involving the imine nitrogen as has been observed for some other schiff base complexes reported. Also the shift observed in the $\mathrm{O}-\mathrm{H}$ stretch of the ligand and those from the complexes suggests that complexation has occurred by involving the oxygen end as has been observed for some other reported cases.

Table4. Infrared Spectra of $B L_{2}$ and its Complexes $\left(\mathrm{cm}^{-1}\right)$

\begin{tabular}{|l|l|l|l|}
\hline $\mathbf{B L}_{2}$ & $\mathbf{C d B L}_{2}$ & $\mathbf{C o B L}_{2}$ & Functional Group \\
\hline $3760.35 \mathrm{w}$ & $3403.51 \mathrm{w}$ & $3757.46 \mathrm{~s}$ & O-H stretching \\
\hline $2978.19 \mathrm{w}$ & $2902.96 \mathrm{br}$ & $2902.00 \mathrm{br}$ & C-H aromatic stretching \\
\hline $1687.77 \mathrm{~s}$ & $1619.29 \mathrm{~m}$ & $1634.73 \mathrm{~m}$ & $\mathrm{C}=\mathrm{O}$ stretching \\
\hline $1453.14 \mathrm{~s}$ & $1420.62 \mathrm{w}$ & $1438.94 \mathrm{w}$ & C=C Aromatic, C=N bending \\
\hline $1137.07 \mathrm{~s}$ & $1038.7 \mathrm{~m}$ & $1041.6 \mathrm{w}$ & C-C, C-O stretching \\
\hline $430.14 \mathrm{br}$ & $468.72 \mathrm{w}$ & $431.1 \mathrm{w}$ & C-C ring \\
\hline
\end{tabular}

* Intensities: s-strong, m-medium, br-broad, w-weak

The proposed structures of the ligands and their metal complexes are given below:<smiles>O=C(O)c1cc(/N=C/c2ccccc2O)cc(/N=C/c2ccccc2O)c1</smiles>

Fig1. $N$, $N$ '-Bis (salicylidene)-3, 5-diaminobenzoic acid, $\left(B L_{2}\right)$ [11]<smiles>Oc1ccccc1/N=C/C/C=N/c1ccccc1O</smiles>

Fig2. $N$, $N$ '-Ethylene bis (salicylidenimine) $\left(E L_{1}\right)$ [10] 
Synthesis, Spectroscopic and Preliminary Antimicrobial Studies of Some Schiff Base Ligands; N'N'Ethylene Bis(salicylidenimine) and N,N'-Bis (salicylidene)-3,5-Diaminobenzoic Acid and their Metal Complexes

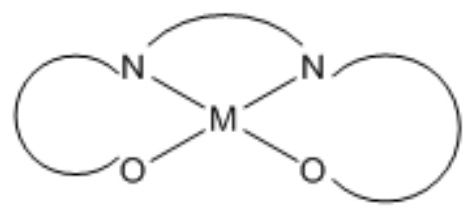

Fig3. Representation of the metal complexes

Where $\mathrm{M}=\mathrm{Fe}, \mathrm{Pb}, \mathrm{Cd}$, and $\mathrm{Co} \quad[10]$

\subsection{Antimicrobial Properties}

In fig 4 below, the result of the activity on both gram positive and gram negative was shown with $\mathrm{CoBL}_{2}$ having the highest zone on the gram negative while $\mathrm{BL}_{2} \mathrm{Cd}$ produced the highest zone on gram positive organism. The lowest zone was produced on gram positive, while ligand $\mathrm{BL}_{2}$ and metal complex of $\mathrm{MgEL}_{1}$ and $\mathrm{CoBL}_{2}$ has no activity on positive organism.

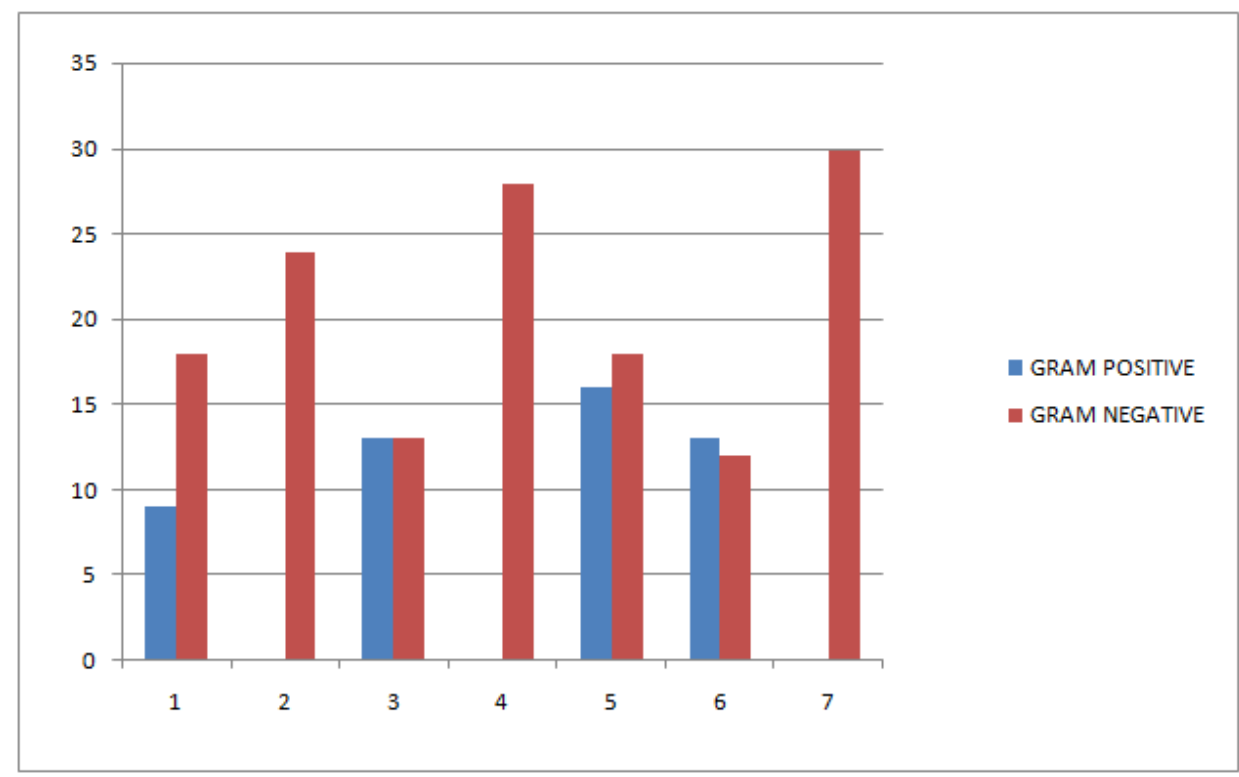

Fig4. Representation of gram negative and gram positive organism

\section{CONCLUSION}

The $\mathrm{Mg}$ (II), $\mathrm{Fe}(\mathrm{II}), \mathrm{Pb}$ (II), $\mathrm{Cd}(\mathrm{II})$ and $\mathrm{Co}(\mathrm{II})$ complexes were synthesized by coupling with the Schiff base $N, N^{\prime}$-ethylene bis (salicylidenimine) and ( $N, N^{\prime}$ bis (salicylidene)-3,5-diamino benzoic acid. The result of the electronic spectra and infrared spectra shows that there was coordination between the ligands and metal complexes. The antimicrobial result showed that the compounds have significant activities on the gram negative organism than on the gram positive organism.

\section{ACKNOWLEDGEMENT}

The authors are very grateful to the Vice Chancellor of Godfrey Okoye University, Enugu, Nigeria for creating a comfortable environment for research. We also acknowledge the technical assistance of the laboratory staff of the Chemical Sciences Department.

\section{REFERENCES}

[1] Hine J. and Yeh C.Y.,(1967), J.Am Chem Soc.,89 2669.

[2] Fessenden R.J., and Fessenden J.S., (1998), Organic Chemistry, Brooks/ Cole publishing Company, USA.

[3] Cimerman Z., Miljanic S. and Galic N., (2000), Crotica Chemica Acta, 7381

[4] Brown . D.H., and Smith.W.E.,(1990), Enzyme Chemistry-impart and Application, Chapmann and Hall, London.

[5] G.H. Schmid, Organic Chemistry, new York, 1996 
Synthesis, Spectroscopic and Preliminary Antimicrobial Studies of Some Schiff Base Ligands; N'N'Ethylene Bis(salicylidenimine) and N,N'-Bis (salicylidene)-3,5-Diaminobenzoic Acid and their Metal Complexes

[6] S. N. Pandey, D. Sriram, G.Nath and E.de Clercy, Arzneimittel Forsch.,50 (2000)55

[7] S.N. Pandey, D. Sriram, G.Nath and E.de Clercy, Pharm. Acta Helv., 74 (1999)11

[8] W.M. Singh and B.C. Dash, Pesticides, 22(1988) 33

[9] J.L.Kelley, J.A. linn, D.D. Bankston, C.J. Burchall, F.E. Soroko and B.R.Cooper, J.Med.chem., 38(1995) 3675

[10] Tawfiq A.AI-Diwan (2010), Synthesis and Characterization of Some Divalent Transition Metals Complete of Schiff Base Derived from Salicylaldehyde Diamine Derivatives, Al-Mustansiriya J.Sci

[11] Chizoba I.E; Oguejiofo. T.U; Pius O.U; and Nkechi U. (2012), Complex Formation and Extraction Studies of N,N'-Bis (Salicylidene)-3,5-Diaminobenzioc Acid on Hg(II) and (I). Chem.Sci Trans, 2 (4), 1118-1125

[12] H.N. Aliyu and I. Ado (2011), Studies of Mn(II) and Ni(II) Complexes with Schiff Base Derived from 2Aminobenzoic Acid and Salicylaldehyde . Biokemistri 23 (1), 9-16

Citation: O. Ugwu Mariagoretti et al., "Synthesis, Spectroscopic and Preliminary Antimicrobial Studies of Some Schiff Base Ligands; N'N'-Ethylene Bis(salicylidenimine) and N,N'-Bis (salicylidene)-3,5Diaminobenzoic Acid and their Metal Complexes", International Journal of Advanced Research in Chemical Science (IJARCS), vol. 4, no. 8, pp. 1-6, 2017. http://dx.doi.org/10.20431/2349-0403.0408001

Copyright: (C) 2017 Authors. This is an open-access article distributed under the terms of the Creative Commons Attribution License, which permits unrestricted use, distribution, and reproduction in any medium, provided the original author and source are credited. 